\title{
Comparison of the Effects of Haloperidol and Benzodiazepines Used for Postictal Psychiatric Symptoms on Seizure Recurrence: A Pilot Study
}

\section{Postiktal Psikiyatrik Semptomlarda Benzodiazepin ve Haloperidolün Nöbet Tekrarına Etkilerinin Karşılaştırılması}

\author{
Pınar Hanife Kara, Erden Erol Ünlüer \\ Izmir Katip Çelebi University Atatürk Training and Research Hospital, Clinic of Emergency Medicine, Izmir, Turkey
}

\section{Abstract}

\begin{abstract}
Aim: Patients with epilepsy may experience a number of psychiatric and cognitive symptoms or behavioral manifestations during the period of a seizure and the postictal period. The aim of this pilot study was to compare the effects medications commonly used in emergency departments for postictal psychiatric symptoms on seizure recurrence.

Methods: Data of 32 epileptic patients, who presented to İzmir Katip Çelebi University Atatürk Research and Training Hospital Emergency Department with postictal psychiatric symptoms between January 2013 and December 2014, were retrospectively collected. Demographic and clinical data were obtained from the emergency department charts and neurology and psychiatry consultation records. Data regarding administered drugs were obtained from the hospital data processing system. The chi-square test, Mann-Whitney $U$ test and the KruskalWallis test were used as statistical methods. Bonferroni correction was performed for post-hoc analysis.
\end{abstract}

Results: There were no differences in the seizure recurrence rate between benzodiazepine, haloperidol and without medication groups ( $p>0.05)$.

Conclusion: Our results suggest that benzodiazepines and haloperidol do not affect the development of recurrent seizures when administered for postictal symptoms.

Keywords: Postictal, emergency department, haloperidol, benzodiazepines
Öz

Amaç: Epilepsi hastaları postiktal dönemlerinde psikiyatrik, bilişsel ve davranışsal semptomlar gösterebilirler. Bu pilot çalışmada acil servislerde postiktal semptomlarda sıklıkla kullanılan haloperidol ve benzodiyazepinin nöbet tekrarına etkisinin karşılaştırıması amaçlanmıştır.

Yöntemler: Ocak 2013 ve Aralık 2014 arasında İmir Katip Çelebi Üniversitesi Atatürk Eğitim ve Araştırma Hastanesi Acil Servisi'nde postiktal psikiyatrik semptomlarla başvurmuş 32 hasta hastane veri kayıt sisteminden taranmıştır. Veri olarak elektronik arşivden acil servis hasta kartları, nöroloji ve psikiyatri konsültasyon kayıtları ve elektronik hemşire order bilgileri kullanılmıştır. İstatistiksel yöntem olarak kikare, Mann-Whitney $U$ ve Kruskal-Wallis testi kullanılmıştır. Post-hoc analizlerde Bonferroni düzeltmesi yapılmıştır.

Bulgular: Nöbet tekrarı açısından benzodiyazepin, haloperidol ve ilaç kullanılmayan gruplar arasında anlamlı fark saptanmamıştır ( $p>0,05)$.

Sonuç: Postiktal psikiyatrik semptomlarda benzodiyazepin ve haloperidolün nöbet tekrarına anlamlı bir etkisi olmadığı saptanmıştır.

Anahtar Sözcükler: Postiktal, acil servis, haloperidol, benzodiyazepin

\section{Introduction}

Healthcare workers, especially general practitioners and emergency department staff, are likely to encounter patients exhibiting aggression and violence. This behavior may be caused by a medical illness, a psychiatric illness, or drug intoxication or withdrawal (1). Agitation is a psychomotor disturbance characterized by markedly increased motor and psychological activity (2). Patients
Address for Correspondence/Yazışma Adresi: Pınar Hanife Kara İzmir Katip Çelebi University Atatürk Training and Research Hospital, Clinic of Emergency Medicine, Izmir, Turkey

E-mail: hpinarkara@hotmail.com ORCID ID: orcid.org/0000-0003-1261-4272

Received/Geliş Tarihi: 19 June 2016 Accepted/Kabul Tarihi: 04 May 2017
${ }^{0}$ Copyright 2017 by The Medical Bulletin of University of Health Sciences Haseki Training and Research Hospital
The Medical Bulletin of Haseki published by Galenos Yayınevi.

'Telif Hakkı 2017 Sağlık Bilimleri Üniversitesi Haseki Eğitim ve Araşıırma Hastanesi Haseki Tıp Bülteni, Galenos Yayınevi tarafından basılmışır. 
with extremely violent, agitated behavior may require treatment with psychotropic medications. However, these drugs have a number of potential side effects, including sedation, ventilatory depression, and seizure threshold changes. Indeed, all antipsychotic drugs have the propensity to cause paroxysmal electroencephalogram abnormalities and induce seizures $(3,4)$. Low-potency antipsychotics are not very safe drugs to be used in the management of acute psychotic episodes. They can cause deep sedation, hypotension, arrhythmia and lowering the seizure threshold. Contrarily high-potency antipsychotics (e.g, haloperidol) are associated with a lower events of excessive sedation, hypotension, lower risk of quinidine related QT prolongation (lower possibility of cardiac arrhythmia), and less effects in reducing the seizure threshold $(4,5)$.

Nineteen to $80 \%$ of epileptic patients experience a psychotic episode at some point during the course of the disease (6). Three types of psychiatric disorders have been described in patients with epilepsy: disorders due to brain abnormalities, disorders directly related to the seizures, and disorders without a direct relationship with the seizures (7). Behavioral changes occur during and immediately after most seizures (8). These changes may be associated with serious morbidity and mortality. Both verbal and physical violence may occur; the latter can cause serious or even life-threatening injuries to the patient or others (9).

Benzodiazepines or atypical antipsychotic drugs are often used to treat postictal psychosis, especially when the psychosis is accompanied by agitation and aggression (1,9-11). Haloperidol can be administered by intramuscular injection, has a rapid onset of action, and acts for 2 to 4 hours. Toxicity manifests as over-sedation or hypotension. Extrapyramidal adverse effects (e.g. dystonia), neuroleptic malignant syndrome, arrhythmias, and akathisia may also occur, even after a single dose of the drug. Haloperidol may also lower the seizure threshold although it appears to be associated with a lower seizure risk than other antipsychotic agents $(1,2,8,12)$.

Increasing doses of benzodiazepines produce a progressive spectrum of effects from anxiolysis and anticonvulsant activity to amnesia, sedation, and eventually hypnosis and anesthesia. Toxicity is usually related to very high doses and results in excessive sedation and airway obstruction. Whereas benzodiazepines are generally safe drugs, they may contribute to cardiovascular and respiratory depression (1).

Postictal psychiatric and cognitive symptoms are known to occur, but their prevalence and clinical characteristics have not been firmly established (13). Some studies showed that midazolam and haloperidol have similar efficacy and safety for the improvement of restless and violent behavior symptoms in patients referred to the emergency department (14). However, no previously published study has evaluated the effects of medications used for postictal psychiatric symptoms on seizure recurrence in emergency department patients. Therefore, the aim of this retrospective, pilot study was to compare the rate of recurrent seizure associated with the administration of drugs commonly used in emergency departments to treat postictal psychiatric symptoms.

\section{Methods}

\section{Study Participants and Data Collection}

Of the 1133 adult admissions to the Izmir Katip Çelebi University Atatürk Research and Training Hospital Emergency Department for epileptic seizures between 01.01.2013 and 30.12.2014, data were retrospectively collected from 32 epileptic patients with postictal psychiatric symptoms. Demographic and clinical data were obtained from the emergency department charts, as well as the neurology and psychiatry consultation records. Information regarding the administered drugs was obtained from the hospital data processing system via electronic nurse order charts.

The exclusion criteria were as follows: children or pregnant women, patients with an intracranial mass, substance abuse, poststroke epilepsy, status epilepticus, or previous shunt operation, seizures secondary to infection or sepsis, electrolyte imbalance, hydrocephalus, alcohol abuse, and pseudo-epilepsy, or drug overdoses.

Psychiatric symptoms were categorized as positive or negative, according to Devinsky's (8) definitions. Positive symptoms included tangential, incoherent speech and thought; hallucinations or delusions; aggression; and exaggerated, bizarre, or disorganized behavior. Negative symptoms included poverty of speech or speech content, flat affect, social withdrawal, anhedonia, apathy, and impaired attention and self-monitoring. If a patient exhibited symptoms belonging to both groups, the symptoms were designated as positive or negative, depending on the group with the greatest number of symptoms. In this study, postictal psychiatric symptoms included agitation, visual hallucinations, homicidal ideation, crying, violence, perseveration, speech failure, stuttering, and social withdrawal. Only those seizures that occurred after treatment for postictal symptoms (with haloperidol, benzodiazepines) or without medication were considered recurrent seizures.

\section{Statistical Analysis}

Statistical analysis was performed using the Statistical Package for the Social Sciences (SPSS-17 ${ }^{\circledR}$ ) for Windows, 
with 95\% confidence intervals. Categorical variables were reported as frequencies and percentages, and continuous variables were reported as mean \pm standard deviation or median (range) values. Numerical variables were examined by the Shapiro-Wilk test for compatibility to a normal distribution. The chi-square test was used to analyze the relationship between categorical variables. The relationship between two independent samples was analyzed using the Mann-Whitney $U$ test, and the KruskalWallis test was used to compare median values for more than two independent samples. Bonferroni correction was performed for post-hoc analysis. Statistical significance was defined as $p<0.05$.

\section{Results}

This study included 32 epileptic patients with postictal psychiatric symptoms. The baseline characteristics of the patients are presented in Table 1. The mean age of the subjects was $39( \pm 15.3)$ years and the mean disease duration was 25 months. Nineteen (59.4\%) patients were male. Epilepsy treatment consisted of just one antiepileptic drug in 21 (65.6\%) patients, no antiepileptic drug in seven $(21.9 \%)$ patients, and multiple drugs for epilepsy in four (12.5\%) patients. An additional psychiatric condition was present in 20 (62.5\%) patients, and seven (21.9\%) patients were chronically receiving a psychiatric drug. In the majority of patients ( $n=21 ; 75 \%)$, the postictal psychiatric symptoms were positive symptoms, whereas in the remaining $25 \%$, the symptoms were negative. Seizure recurrence occurred in seven (21.9\%) patients. After receiving treatment for the postictal symptoms, nine $(28.1 \%)$ patients were admitted to the hospital and $23(71.9 \%)$ were discharged home. The seizures were generalized tonic-clonic in 29 (90.6\%) patients and focal in three (9.4\%).

Comparison of the benzodiazepine, haloperidol and without medication groups is shown in Table 2. Gender, age, disease duration, additional psychiatric disease, prognosis, and seizure type did not differ between the three groups ( $p>0.05$ ). Additionaly, there was no difference in the rate of seizure recurrence between the three groups $(p>0.05)$. Positive symptoms were more common in the benzodiazepine and haloperidol groups and patients with positive symptoms were more likely to receive haloperidol and benzodiazepine as medication $(p<0.05)$.

The relationship between seizure recurrence and other variables is shown in Table 3. Gender, age, disease duration, prognosis, seizure type, and types of psychiatric symptoms (positive or negative) did not differ between patients who did or did not have a recurrent seizure $(p>0.05)$. The patients with seizure recurrence were more likely to be hospitalized than patients with no seizure recurrence. The relationship between the types of postictal psychiatric symptoms and other variables is presented in Table 4 . Gender, age, disease duration, prognosis, and seizure type did not differ between patients with positive or negative symptoms $(p>0.05)$.

\section{Discussion}

The postictal period is defined by changes in behavior, motor function, and neuropsychological performance that last until the return to a presumed baseline $(15,16)$. Postictal behavioral changes can include psychosis, aggression, and mood changes, and many of them are commonly observed in patients with epilepsy (17). Postictal symptoms differ in seriousness, duration, and response to treatment with interictal symptomatology (18).

\begin{tabular}{|l|l|}
\hline \multicolumn{2}{|l|}{ Table 1. Patient demographics and other characteristics } \\
\hline Variable & Value \\
\hline Age (y) & $39.0 \pm 15.3$ \\
\hline Gender & \\
\hline Male & $19(59.4)$ \\
\hline Female & $13(40.6)$ \\
\hline Disease duration (mo) & $25.0(0-456)$ \\
\hline Chronic antiepileptic drug use & \\
\hline None & $7(21.9)$ \\
\hline Single drug & $21(65.6)$ \\
\hline Multiple drugs & $4(12.5)$ \\
\hline Additional psychiatric disorder & \\
\hline No & $20(62.5)$ \\
\hline Yes & $12(37.5)$ \\
\hline Psychiatric drug & \\
\hline No & $25(78.1)$ \\
\hline Yes & $7(21.9)$ \\
\hline Symptoms & $29(95.0)$ \\
\hline Negative & $25(78.1)$ \\
\hline Positive & $7(21.9)$ \\
\hline Seizure recurrence & \\
\hline No & \\
\hline Yes & \\
\hline Disposition & \\
\hline Discharged & \\
\hline Hospitalized & \\
\hline Seizure type & \\
\hline Generalized & \\
\hline Focal & \\
\hline
\end{tabular}


Violent behavior is observed in postictal confusion as an evidence of unconscious, strong resistance against efforts of surrounding people to prevent the affected individual from walking around or fumbling about (19). Postictal behaviors and symptoms often require special evaluation and treatment. Medical and emergency physicians needs featured education to manage behaviors associated with postictal symptoms in order to protect patients while their confusion resolving (4).

The pathophysiological causes of postictal psychosis are poorly understood (6). Neural damage, brain extracellular glutamate levels (20), limbic psychotic trigger reaction (21), dysfunction involving the medial temporal and prefrontal cortex (22), substantial changes in cerebral blood flow, endogenous opiates, and changes in monoamines (3) have all been implicated in the development of postictal behavioral problems.
Agitation is a psychomotor disturbance characterized by a marked increase in motor and psychological activity, which can cause major interference with assessment and treatment in the healthcare setting $(2,10)$. It consists of aggressive and non-aggressive components, which may be verbal and/or physical in nature (10). Current evidence indicates that there is muchvariability in the approach of agitation in emergency department settings (10-12,23). Soever, quick and effective pharmacological treatment is often required to be sure for the safety of patients, as well as healthcare providers (10).

Haloperidol and benzodiazepines are among the most widely used agents for agitation (1,9-11). Rapid tranquilization is a routine method for agitated psychotic patients by use of neuroleptics, benzodiazepines, or both (24). The most frequently used drugs to control psychomotor agitation include classical antipsychotics like haloperidol or benzodiazepines like diazepam (5).

\begin{tabular}{|c|c|c|c|c|}
\hline & $\begin{array}{l}\text { Without medication } \\
(n=7)\end{array}$ & $\begin{array}{l}\text { Benzodiazepin } \\
(n=18)\end{array}$ & $\begin{array}{l}\text { Haloperidol } \\
(n=7)\end{array}$ & p \\
\hline Age $(y)$ & $40.7 \pm 13.2$ & $37.7 \pm 18.1$ & $40.4 \pm 10.2$ & 0.726 \\
\hline \multicolumn{5}{|l|}{ Gender } \\
\hline Male & $5(71.4)$ & $11(61.1)$ & $3(42.9)$ & \multirow{2}{*}{0.572} \\
\hline Female & $2(28.6)$ & $7(38.9)$ & $4(57.1)$ & \\
\hline Disease duration (mo) & $30(1-264)$ & $12.5(0-420)$ & $192.5(0-456)$ & 0.258 \\
\hline \multicolumn{5}{|c|}{ Additional psychiatric disorder (n, \%) } \\
\hline No & $5(71.4)$ & $11(61.1)$ & $4(57.1)$ & \multirow{2}{*}{0.899} \\
\hline Yes & $2(28.6)$ & $7(38.9)$ & $3(42.9)$ & \\
\hline \multicolumn{5}{|l|}{ Psychiatric drug (n, \%) } \\
\hline No & $6(85.7)$ & $15(83.3)$ & $4(57.1)$ & \multirow{2}{*}{0.501} \\
\hline Yes & $1(14.3)$ & $3(16.7)$ & $3(42.9)$ & \\
\hline \multicolumn{5}{|l|}{ Symptoms (n, \%) } \\
\hline Negative & $6(85.7)$ & $2(11.1)$ & $0(0)$ & \multirow{2}{*}{$<0.001^{a}, \mathrm{~b}$} \\
\hline Positive & $1(14.3)$ & $16(88.9)$ & $7(100)$ & \\
\hline \multicolumn{5}{|l|}{ Seizure recurrence $(n, \%)$} \\
\hline No & $5(71.4)$ & $14(77.8)$ & $6(85.7)$ & \multirow{2}{*}{$>0.999$} \\
\hline Yes & $2(28.6)$ & $4(22.2)$ & $1(14.3)$ & \\
\hline \multicolumn{5}{|l|}{ Disposition (n, \%) } \\
\hline Discharged & $5(71.4)$ & $13(72.2)$ & $5(71.4)$ & \multirow{2}{*}{$>0.999$} \\
\hline Hospitalized & $2(28.6)$ & $5(27.8)$ & $2(28.6)$ & \\
\hline \multicolumn{5}{|l|}{ Seizure type (n, \%) } \\
\hline Generalized & $5(71.4)$ & $18(100)$ & $6(85.7)$ & \multirow{2}{*}{0.073} \\
\hline Focal & $2(28.6)$ & $0(0)$ & $1(14.3)$ & \\
\hline
\end{tabular}


In the current study, benzodiazepines and haloperidol were administered most commonly to patients with positive symptoms, and patients with negative symptoms could not take medication for their signs. The use of haloperidol and benzodiazepines in patients with positive psychotic symptoms, including aggression, is consistent with medical approaches reported in the literature (1,911).

Neither haloperidol nor benzodiazepines affected the rate of seizure recurrence in the current study. The recurrence

\begin{tabular}{|c|c|c|c|}
\hline \multirow[t]{2}{*}{ Variable } & \multicolumn{2}{|c|}{ Seizure recurrence } & \multirow[t]{2}{*}{$\mathbf{p}$} \\
\hline & No & Yes & \\
\hline Age (y) & $41.0 \pm 15.3$ & $31.7 \pm 14.2$ & 0.138 \\
\hline \multicolumn{4}{|l|}{ Gender } \\
\hline Male & $14(56.0)$ & $5(71.4)$ & \multirow{2}{*}{0.671} \\
\hline Female & $11(44.0)$ & $2(28.6)$ & \\
\hline Disease duration (mo) & $30.0(0-456)$ & $19.0(1-456)$ & 0.446 \\
\hline \multicolumn{4}{|l|}{ Seizure type } \\
\hline Generalized & $23(92.0)$ & $6(85.7)$ & \multirow{2}{*}{0.536} \\
\hline Focal & $2(8.0)$ & $1(14.3)$ & \\
\hline \multicolumn{4}{|l|}{ Disposition } \\
\hline Discharged & $22(88.0)$ & $1(14.3)$ & \multirow{2}{*}{0.001} \\
\hline Hospitalized & $3(12.0)$ & $6(85.7)$ & \\
\hline \multicolumn{4}{|l|}{ Symptoms } \\
\hline Negative & $6(24.0)$ & $2(28.6)$ & \multirow{2}{*}{$>0.999$} \\
\hline Positive & $19(76.0)$ & $5(71.4)$ & \\
\hline
\end{tabular}

Table 4. Relationships between symptom type and other variables

\begin{tabular}{|c|c|c|c|}
\hline \multirow[t]{2}{*}{ Variable } & \multicolumn{2}{|l|}{ Symptoms } & \multirow[t]{2}{*}{$p$} \\
\hline & Negative & Positive & \\
\hline Age $(y)$ & $38.8(13.3)$ & $39.0(16.2)$ & 0.913 \\
\hline \multicolumn{4}{|l|}{ Gender } \\
\hline Male & $6(75.0)$ & $13(54.2)$ & \multirow{2}{*}{0.420} \\
\hline Female & $2(25.0)$ & $11(45.8)$ & \\
\hline Disease duration (mo) & $39.0(1-264)$ & $24.0(0-456)$ & 0.605 \\
\hline \multicolumn{4}{|l|}{ Seizure type } \\
\hline Generalized & $6(75.0)$ & $23(95.8)$ & \multirow{2}{*}{0.147} \\
\hline Focal & $2(25.0)$ & $1(4.2)$ & \\
\hline \multicolumn{4}{|l|}{ Disposition } \\
\hline Discharged & $6(75.0)$ & $17(70.8)$ & \multirow{2}{*}{$>0.999$} \\
\hline Hospitalized & $2(25.0)$ & $7(29.2)$ & \\
\hline
\end{tabular}

rate was similar in haloperidol and benzodiazepine groups and in patients without medication. The lack of effect was observed despite the potential for haloperidol to lower the seizure threshold. Thus, in this first published study comparing these drugs for postictal psychiatric symptoms in an emergency department setting, both seem to be appropriate to use with respect to seizure recurrence.

\section{Study Limitations}

This study has limitations. It is a retrospective study, with the typical limitations inherent in this study design. Besides, the number of patients was small. Although a small number was planned, as this was merely a pilot study, large randomized controlled trials should be performed in the future to confirm our results. Furthermore, other potential complications (besides seizure recurrence) associated with the use of haloperidol or benzodiazepines were not recorded, as this information was not readily available in the reviewed records. However, the most serious complications, such as potentially lethal cardiac arrhythmias (torsade de pointes) with haloperidol (10) or severe respiratory depression with benzodiazepines (10) are rare and would not likely be detected by a small pilot study.

\section{Conclusion}

Patients with epilepsy may experience a number of psychiatric and cognitive symptoms or behavioral manifestations around the time of a seizure. When treating agitation in the postictal period, the effect of medications on seizure recurrence is a potential concern. Our study demonstrated that haloperidol and benzodiazepines did not affect the risk of seizure recurrence compared to that in those receiving no medication. Thus, we assume that to avoid using these drugs in the postictal period is not necessary.

\section{Ethics}

Ethics Committee Approval: Retrospectively study.

Informed Consent: Retrospectively study.

Peer-review: Internally peer-reviewed.

\section{Authorship Contributions}

Surgical and Medical Practices: P.H.K. Concept: P.H.K. Design: P.H.K. Data Collection or Processing: P.H.K., E.E.Ü. Analysis or Interpretation: E.E.Ü., P.H.K. Literature Search: E.E.Ü., P.H.K. Writing: P.H.K.

Conflict of Interest: No conflict of interest was declared by the authors.

Financial Disclosure: The authors declared that this study received no financial support.

\section{References}

1. Fulde G, Preisz P. Managing aggresive and violent patients. Australian Prescriber 2011;34:115-8. 
2. Chevrolet JC, Jolliet P. Clinical review: agitation and delirium in the critically ill-significance and management. Crit Care 2007;11:214.

3. Sachdev PS. Alternating and postictal psychoses: review and a unifying hypothesis. Schizophr Bull 2007;33:1029-37.

4. Krauss G, Theodore WH. Treatment strategies in the postictal state. Epilepsy Behav 2010;19:188-90.

5. Mantovani C, Migon MN, Alheira FV, Del-Ben CM. Managing agitated or aggressive patients manejo de paciente agitadu ou agressivo. Rev Bras Psiquiatr 2010;32(Suppl 2):96-103.

6. González Mingot C, Gil Villar MP, Calvo Medel D, et al. Epileptic peri-ictal psychosis, a reversible cause of psychosis. Neurologia 2013;28:81-7.

7. Adachi N, Matsuura M, Hara T, et al. Psychoses and epilepsy: are interictal and postictal psychoses distinct clinical entities? Epilepsia 2002;43:1574-82.

8. Devinsky O. Therapy for neurobehavioral disorders in epilepsy. Epilepsia 2004;45(Suppl 2):34-40.

9. Devinsky O. Postictal psychosis: common, dangerous, and treatable. Epilepsy Curr 2008;8:31-4.

10. Pacciardi B, Mauri M, Cargioli C, et al. Issues in the management of acute agitation: how much current guidelines consider safety? Front Psychiatry 2013;7:4-26.

11. Alexander J, Tharyan P, Adams C, John T, Mol C, Philip J. Rapid tranquillisation of violent or agitated patients in a psychiatric emergency setting. Pragmatic randomised trial of intramuscular lorazepam v. haloperidol plus promethazine. $\mathrm{Br}$ J Psychiatry 2004;185:63-9.

12. Esmailian M, Ahmadi O, Taheri M, Zamani M. Comparison of haloperidol and midazolam in restless management of patients referred to the Emergency Department: A double-blinded, randomized clinical trial. J Res Med Sci 2015;20:844-9.

13. Kanner AM, Soto A, Gross-Kanner H. Prevalence and clinical characteristics of postictal psychiatric symptoms in partial epilepsy. Neurology 2004;62:708-13.
14. Esmailian M, Ahmadi O, Taheri M, Zamani M. Comparison of haloperidol and midazolam in restless management of patients referred to the Emergency Department: A double-blinded, randomized clinical trial. J Res Med Sci 2015;20:844-9.

15. Rémi J, Noachtar S. Clinical features of the postictal state: correlation with seizure variables. Epilepsy Behav 2010;19:114-7.

16. Fisher RS, Engel JJ Jr. Definition of the postictal state: when does it start and end? Epilepsy Behav 2010;19:100-4.

17. Ito M. Neuropsychiatric evaluations of postictal behavioral changes. Epilepsy Behav 2010;19:134-7.

18. Kanner AM. Recognition of the various expressions of anxiety, psychosis, and aggression in epilepsy. Epilepsia 2004;45:22-7.

19. Kanemoto K, Tadokoro Y, Oshima T. Violence and postictal psychosis: a comparison of postictal psychosis, interictal psychosis, and postictal confusion. Epilepsy Behav 2010;19:162-6.

20. Cornaggia CM, Beghi M, Provenzi M, Beghi E. Correlation between cognition and behavior in epilepsy. Epilepsia 2006;47(Suppl 2):34-9.

21. Verhoeven WM, Egger JI, Gunning WB, Bevers M, De Pont BJ. Recurrent schizophrenia-like psychosis as first manifestation of epilepsy: a diagnostic challenge in neuropsychiatry. Neuropsychiatr Dis Treat 2010;6:227-31.

22. Tassinari CA, Tassi L, Calandra-Buonaura G, et al. Biting behavior, aggression, and seizures. Epilepsia 2005;46:654-63.

23. Pandya NS, Vrbancic M, Ladino LD, Tellez-Zenteno JF. Epilepsy and homicide. Neuropsychiatr Dis Treat 2013;9:667-73.

24. Battaglia J, Moss S, Rush J, et al. Haloperidol, lorazepam, or both for psychotic agitation? A multicenter, prospective, double-blind, emergency department study. Am J Emerg Med 1997;15:335-40. 